\title{
陝北榆林定邊間流動沙丘及其改造
}

\author{
嚴 欽 劣
}

（華菓所籍大學地理梁）

\section{一 沙亚分佈}

\section{甲. 分佈概况}

傸北流動沙丘主要集中在榆林專區六縣: 定

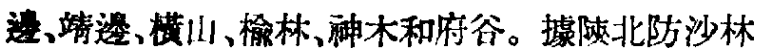
局估計，明沙（隨風移動的流沙）分侑面積約佔
全區總面積 40\%。在定逶與榆林間沙區的南方, 有一相當明顯的界綫。逯悠界緎自定透開始, 經 張家畔, 折向東北, 沿藘河到波穛, 再東行, 沿無 定河至魚河㷛。界綫的東南、東及南方，沙丘極 少, 而且也是分散和小塊的。界綫的西北、西及 北方才是流沙猖独之地（喟1）。

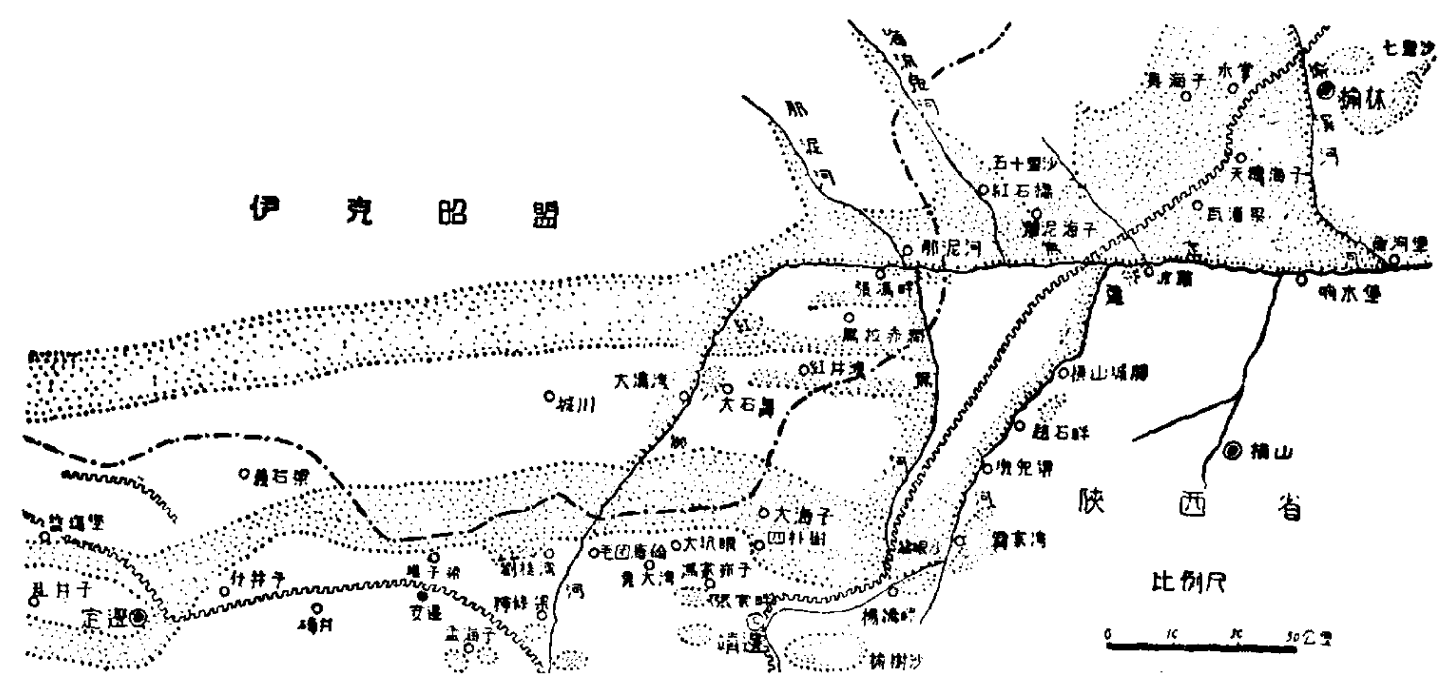

蹻 1 傸北及伊克昭盟南部沙巨: 温域圆

沙㖇的北界則較模糊，因榆林以西，無定河 以北區域，固定沙地與明沙成大牙交錯的分俳情 形，難以正確劃出一佟界䋐來。

\section{乙. 影響分仿性的因素}

任何沙丘堮域，常須具備下列烧倜條件，即 要有充分的沙源, 低等的地形, 然後再經風陣的 堆皘。關於陮北沙丘的沙源將在下節說明，這裏 先論風向與地形。

1. 沙粒向東南移趿：在伊克昭盟和惐北，全 年風向以西北風發生次数最多，尤其春季風最第 强勁，它垶於沙粒向東南移動起了主導作用。至 於東南風和南風, 每年發生於夏季和秋季, 吹刮特 闻既短，風力亦較西北風篇弱，而且這時雨量較
多, 植物生長尔較密, 网此東南風和南風部於沙 柆的浑動便居於次要地位。只有在三浐（定透、

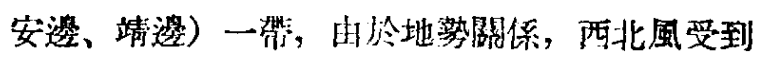

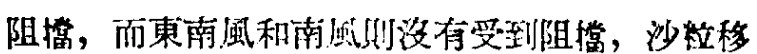
動便發生了變化。

2. 南川擋沙：在地質權造上，成北（包括黄

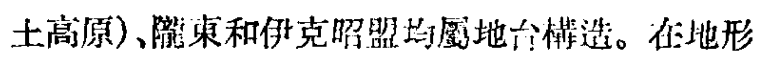

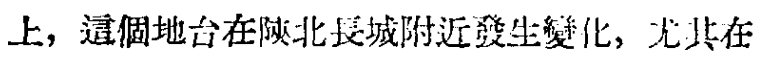

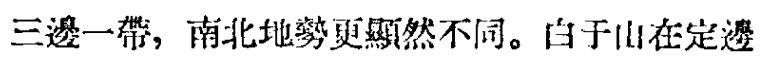
和張家畔之南, 北篇湴地, 南㣪高原, 南進沙粒

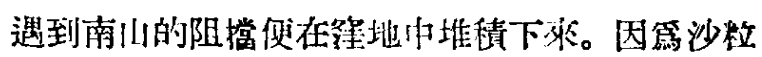

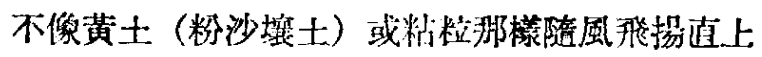
天空，而必須以微楥科坡或平坦地面作基礎，才 
能逐步跳躍前進，因此，南川就成篇沙區南江明 顯的界綫了。

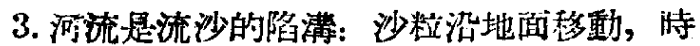
起特落, 呈鸺曲度不大的扡物綫運動, 據德人㞯 頓的笅察，各種沙粒一一次躍進的距離如下表:

沙粒通徑 (琶米) 沙粒一次跧進距離的限度 $1-0.25$ (粗沙及中沙) 25 公尺
$0.25-0.125$
$0.125-0.062\}$ (細沙)
1.5 公里
$0.062-0.031$
$0.031-0.016$
(粉沙)
7.5 公里
300 公里
1,500 公里

從上表可知粗沙及中沙一次躍進距離是很短 的，它艏法一次跳過寞濶的河谷，只有細沙和粉 沙才能越過河谷前進。波羅到魚河堡之間的無定 河，河谷兩壁宽約 2.5一6 公里，因此 便成䉆流 沙的陷溝。賽際上，不僅大河是如此，其他如榆 湓河、海流鬼河、那泥河、蘆河和黑河等莫不有 同㮈作用。即稂林城東的小河，也能阻擋沙粒的 前進（圖2)。流沙既向東南移動, 凡河流的西北、 西及北岸，便厚樍流沙，沙丘高度亦大，河底冲 精平原全部或大部被沙埋壓。反之, 河流的東南、 東及南岸，流沙较少，沙丘低矮，冲積平原少受
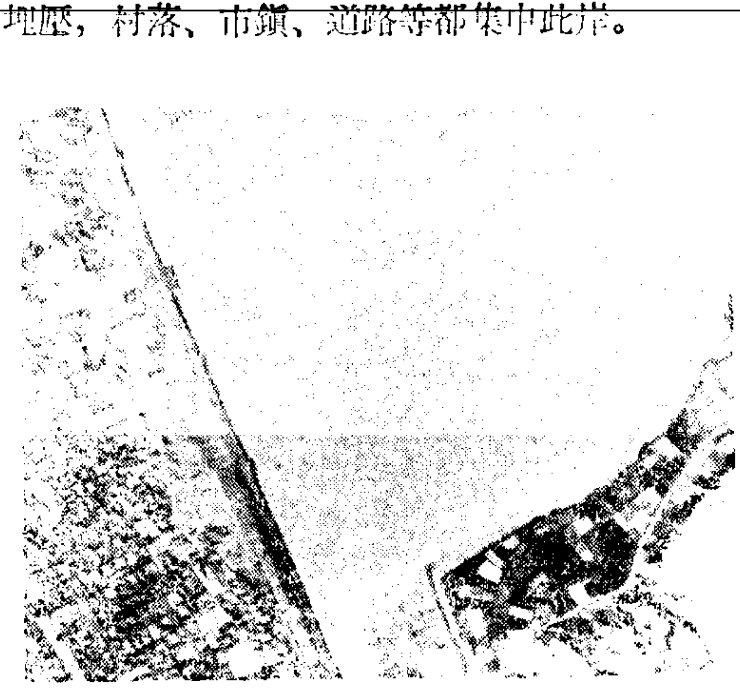

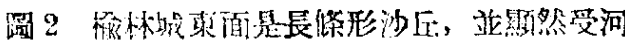

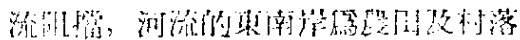

自然，河流規模的大小，亦相碓地影響阻沙 作用的大小。同時不僅細沙、粉沙可以越河而過， 即粗沙和中沙，落到河底後，流水不一定能把它 全部冲走，尤其在河水低降或乾洞期間，經風力 搬通，它們仍可逐步向東南、東及南岸繼綡前進， 因此在河流東南方面谷地裏也常見河岸沙丘。如

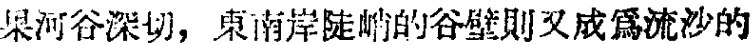
屏陾。由此可知, 如修建護岸林以減少河流的泥 沙量, 则重默箩在河流的西北、西及北岸, 如目 的僅在護田護路, 則重點罂在東南、東及南岸。

4. 三邊地勢與沙帶: 三透，黑河以西地回及 伊克昭盟、城川一带，有東西行梁地並行排列，高 出地面自數十公尺至 200 公尺不等。网個深地之

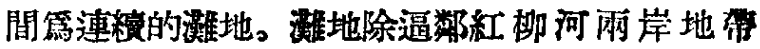

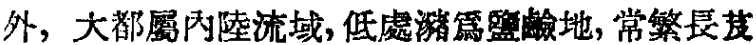
芝草、紅柳、馬蘭、泡泡制等。梁地與踓地䙾度約自 5一20 公里不等。造種地勢，新於沙丘分们起了 一定的規格作用。梁地西北坡篇迎風一面，稹沙 甚少或極薄。流沙以梁第屏，在背風的南坡低處 及梁麓大量堆樍，亚向下伸入灌地低處，因此明 沙亦成東西帶狀分佈了。

\section{二 明沙的由来}

形成廣大的流動沙丘一一明沙，必須有充分 的沙源。在傸北和伊克昭盟，不稐在白㤠紀砂頁 岩、第三紀紅士、第三紀末期或第四紀初期的紅 色士，以及紅色土系以後的河流古代、現代冲栍

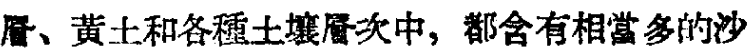
量，沙源是並不匮乏的。

問題在於：這些沙柆通過什密檬的途徑形成 了現在的明沙? 關於這方面有爾種提法:

1. 由於伊克昭盟沙粒向東南運來。

2. 由於人類不合理使用土地，破壞地面植被， 使古沙翻新，縒風搂刮後堆皘成雼明沙一一就地 起沙。

第一種提法，即伊克昭盟沙粒南運，是在長 時期內不斷淮行着，否则無法解釋一般沙地分佈 性質的。但就訪問所知，闲北明沙在最近二、三 百年來才大大地猖慨起來。再從現在自然植物生 長情况來看，幾年封山，即使流動相當迅速的明 沙亦能逐潮周定。這也說明，如没有人篇破壤， 䐣植物生長速度不僅能應付南進的沙柆, 而且 有餘力遏止已經流動的沙丘。換句話說，如人類 不破壤植被，南進的沙粒只能增厚固定沙地的原 度，而不足以直接造成明沙。

第二種提法一一就地起沙，即由於人類不合 理使用土地，破髙植被，是形成明沙的主要原因， 其根據下列諸點:

11月號科學通報 
1. 搝各地居民反映，現在沙臨原第蒙族人民 居佳, 在漢人移入前, 明少分佈不廣。近二、三百年

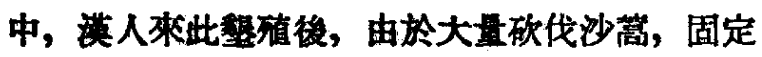

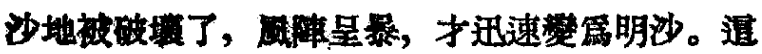
也可從大片明地與人居住地相裳吻合的情形

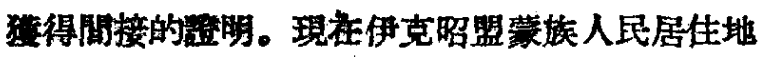

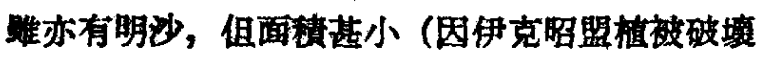
程度不若彂北之甚)。

2. 使北自然境，䨘筒草原地带。数年封山

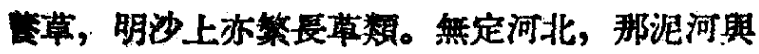
海流思河之間的五十里少，東西兩端，因沿河居 民濫伐沙蓞、烅标，便形成 40-60公尺起伏的大 升，中段約 35 里無人居住的地帶却篇 起 伏微

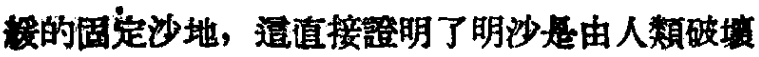
植被後而引起的。

3. 明沙區內有一種極常見的富含有機筫的黑

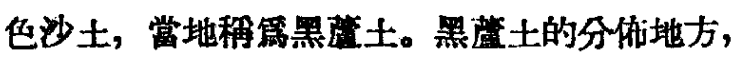
一蚛起伏相當平縓，常成墽台狀残立於沙丘之間， 其高度常低於沙丘頂部，而高於沙简低部(圆3)。

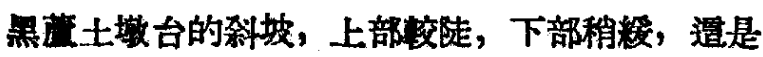

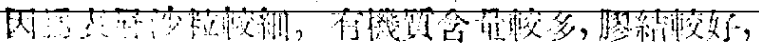

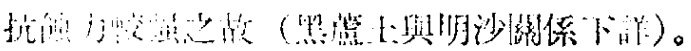

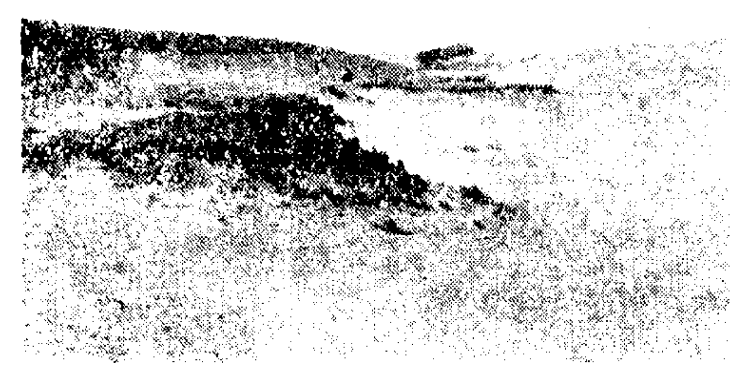

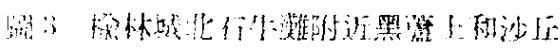

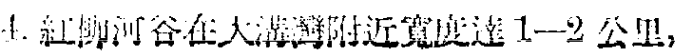
染能約 100 公尺，㖶於向東南前進的粗沙和中沙，

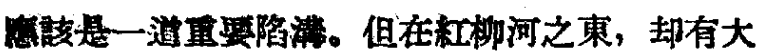
片明沙分倠，並有大量的粗沙、中沙，沙帶東西 延繶情形，不因紅柳河谷而中断，逪種現象是難

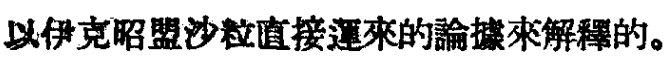

万. 現在㳔北沙丘每年向東南、東及南方前進 味贯一般第 2-5 公尺, 如果以薄沙地每年推 進 15 公尺的最大移動速度計算, 則漢人愁殖的二、

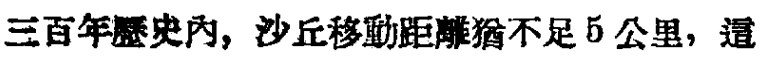

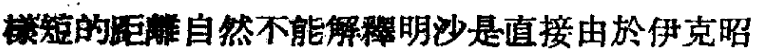
盟沙粒萣來的。

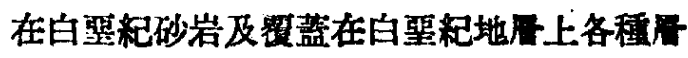
次都含有沙柆。既然流動沙丘以就地起沙篇主， 那末最接近地表的展次與明沙的關係就最篇密 切。在伊克昭盟和傸北的篞地低處發育着濕土， 在明沙區常見黑落土，㯰兩種士届必須特别提出 討論。

有人提出, 瀑土是供給明沙的沙源。然就治 途觀察，涳地中的沙丘㨁接覆蓝在烝土之上，很

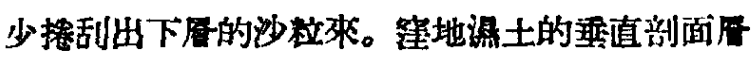
次常很分明, 就㛫橋畔藏河谷弯所見剖面來說,

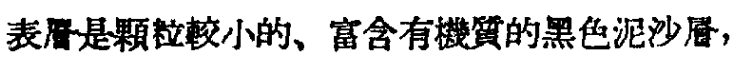
厚自本公尺至一、二公尺不等。下筬灰白色泥沙 展, 當地稱䍃白膠泥。更下篇純黄色沙粒啳, 常 見銹斑。缹土表面黑白雨居都極敉密，也不透

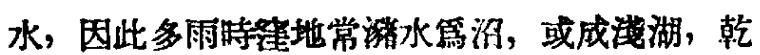

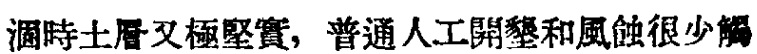

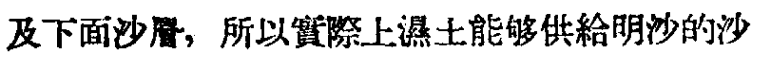
量是非常有限的。

在明沙區內，最常見的是黑展土。黑薄土興 注地瀑土不同, 垂值剖面上没有截然分明的厓次。

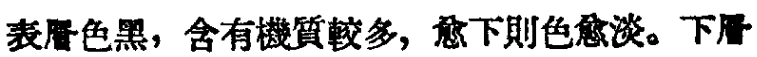
並有小型石灰結核, 表展受雨水冲刷後, 石灰結 核便暴露於地表（紅色士與紅士中石灰結核更 多)。全部組成物質以沙柆篇主。黑薄士厚次踓伿 本整，但仍可見微度傾斜，且上下居有交錯倠叠 現象, 與经地瀑土近於水平狀者很不相同。凡此

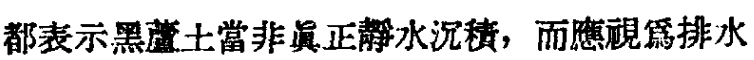
良好的草原土烄, 即有笙地沉棈亦是小規模而且

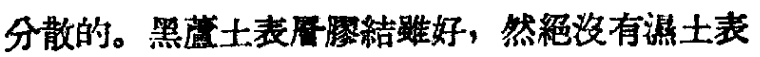

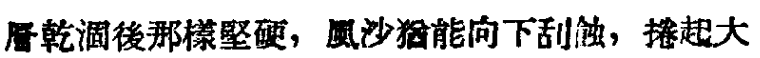
量沙粒。

從黑薄土分作的廣泛, 其分佈醒與明沙地的 十分吻合，以及黑颜土地面一部分被風䘅變低， 一部分又第流沙掩㴕等情形來看, 它與明沙的關 係應該是十分密切的。

\section{三 沙丘的類型、形憼和移動}

甲. 類型

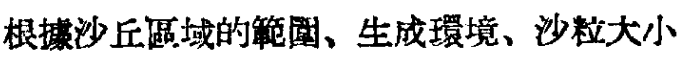
等各方面情形, 可將傸北、伊克昭盟南部沙丘分 篇下列四種類型:

1. 基翰沙區和沙帶: 遭一類沙區分作透䦠， 
沙粒中以粗沙及中沙含量最多, 也有一定量的細 沙，而粉沙和粘粒則極少，茲特稱之基基幹沙。 如㮁林以西、無定河以北的沙區成片狀分侑。三 透沙區則成帶狀分佈，在靖遥一帶，沙帶越城堡

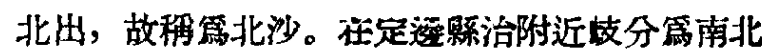
雨帶。

茲將基幹沙确及沙帶內，所探沙嵄的各類沙 粒所佔重量百分比列表如下 (鮧威同志分析):

\begin{tabular}{|c|c|c|c|c|c|}
\hline 地點 & $\begin{array}{l}1.5-0.5 \\
\text { (粗沙) }\end{array}$ & $\begin{array}{c}0.5-0.25 \\
\text { (中沙) }\end{array}$ & $\begin{array}{c}0.25-0.05 \\
(\text { 細沙 })\end{array}$ & $\begin{array}{c}0.05-0.002 \\
(\text { 物沙 })\end{array}$ & $\begin{array}{c}0.002 \text { 以下 } \\
\text { (粘粒) }\end{array}$ \\
\hline 樰 林 七 里 沙 & 76.26 & 20.76 & 1.49 & 0.45 & 0.74 \\
\hline 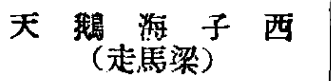 & 3.75 & 65.92 & 24.19 & 0.68 & 0.48 \\
\hline 䢴 泥 河 北 & 41.63 & 53.82 & 2.95 & 1.00 & 0.60 \\
\hline 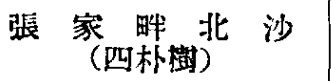 & 1.46 & 83.43 & 10.04 & 4.70 & 0.37 \\
\hline $\begin{array}{l}\text { 劉 } \\
\text { (大粱酒) }\end{array}$ & 0.91 & 77.26 & 14.81 & 6.91 & 0.10 \\
\hline 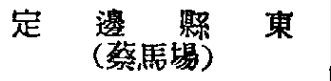 & 6.88 & 65.25 & 22.65 & 3.82 & 1.40 \\
\hline
\end{tabular}

綜觀上列各地沙樣，可知粗沙及中沙一般含 量 70-97\% (天鵝海子西走馬梁、榆林七里沙)， 細沙含量 1.5一-24\%（榆林七里沙、天揚海子西 走馬梁)，粉沙及粘粒会量在 $7 \%$ 以下（劉桂潄、 大梁灣)。基幹沙沙粒既粗，沙屋又厚，易於透水， 潛水面亦較深，因此表面沙庴亦較乾燥。如沙下

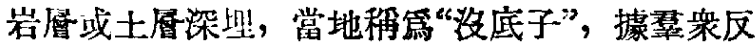
胦，“沟底子”地造喬林林乔望不大，只能臤灌木 如沙㚹、烏柳，多年生草類如沙营等最屋適宜。罜 因基幹沙不僅較乾，且少粉沙粘粒，沙而遠離土 居峲㕆，樹木不易扎根並吸收養分。由那洰河東
五十里沙亦可證明蕀竞經驗是正確的，五十里沙 中段 35 里固定沙地內, 只有沙学、沙挪和臭怕等, 榆樹僅見一棵，高不及五公尺，獨立路产，行人 視䉆䏡樹（可能由於該地岩屡較接近地表)，可見

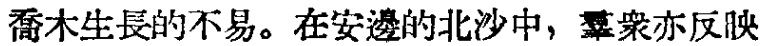
歴次造㸗木林均未獲成功。

2.沙近丵：定邊縣治酒北的監場堡，西证的

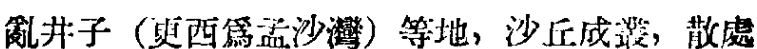
於牛固定沙地之間。自此地向東不遠，即篇連独 的沙帶。沙丘叢的沙料大小客差不一。

\begin{tabular}{|c|c|c|c|c|c|}
\hline 地 繁 & $\begin{array}{r}1.5-0.5 \\
(\text { 粗沙) }\end{array}$ & $\begin{array}{l}0.5-0.25 \\
\text { (中沙) }\end{array}$ & $\begin{array}{c}0.25-0.05 \\
(\text { 細沙 })\end{array}$ & $\begin{array}{c}0.05-0.002 \\
(\text { 汾沙) }\end{array}$ & $\begin{array}{c}0.002 \text { 以下 } \\
\text { (粘粒) }\end{array}$ \\
\hline 定 邀 䅧 皆 堡 & 1.81 & - $\quad 37.90$ & 52.46 & 6.59 & 1.25 \\
\hline
\end{tabular}

3. 內沙: 安邊東南孟海子一帶, 張家畔之西

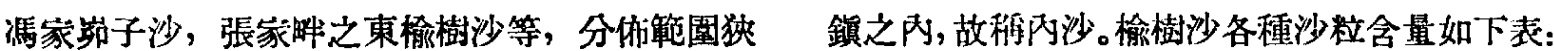

\begin{tabular}{|c|c|c|c|c|c|}
\hline 沙粘值徑 (赛米) & $1.5-0.5$ & $0.5-0.25$ & & & 0.002 以下 \\
\hline 地點 会 & (粗沙) & (中沙) & （細沙） & (粉沙) & （粘粘） \\
\hline 張家畔 榆樹 沙 & - & 0.62 & 88.16 & 10.01 & 1.20 \\
\hline
\end{tabular}




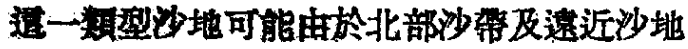

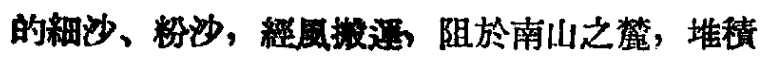

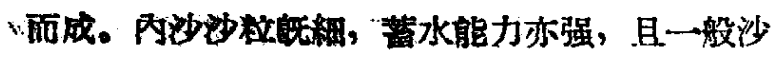

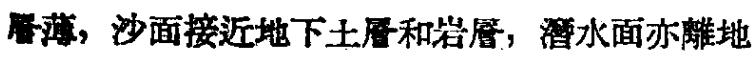
不薏, 當地稱之篇“有底子”。現在陕北所造喬木 林（以彻杫管主）都選提此類沙地裁種。如風力 不烈, 沙下地面無石灰結核, 則內沙確爱易於改 浩的沙地。

4. 河岸沙: 沿河地带的河岸沙，一般規模不 大。就存在地位面㬏，一種在河流東南岸低處本 原上者, 如魚河堡至米脂一段的無定河谷底、横 山城睤至趍石畔一段的花河谷底均有存在, 主要 称汾，亦可挟一定量的粗沙和中沙。另有一種 河岸沙地位高起, 往往堆積於河谷東南岸高處台 地上，逭在無定河谷地，茫河谷地常可見到，沙

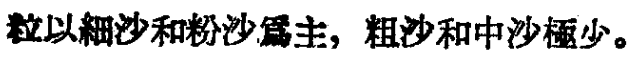

\section{乙. 形狀}

沙丘有迎風坡與背風坡。迎風坡一面坡度较

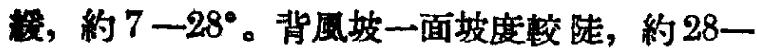
35•。一般迎風坡面向西北方, 如受地勢影響亦可 改方向，龙其沿河谷地带最爱顯著。如梌添河 谷中，沙仃迎風坡向北方，無定河谷中沙丘迎風 坡有稍眮西方現象。

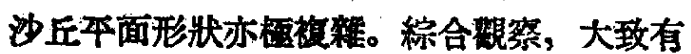
二種基本形式:（1）新月形沙丘。沙丘迎風坡中 部凸出，雨側向背風一面後筑沙埂，諸沙埂互 相連接，個等頂栈便成张形曲（圖 4)，在基 幹沙带和沙踽中, 沙丘商大而且密集之地都成此

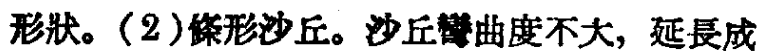

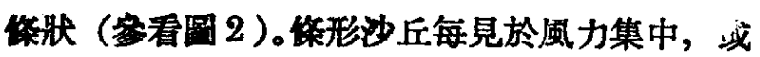

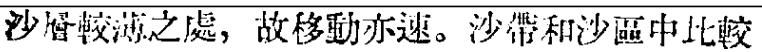

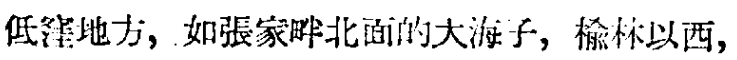

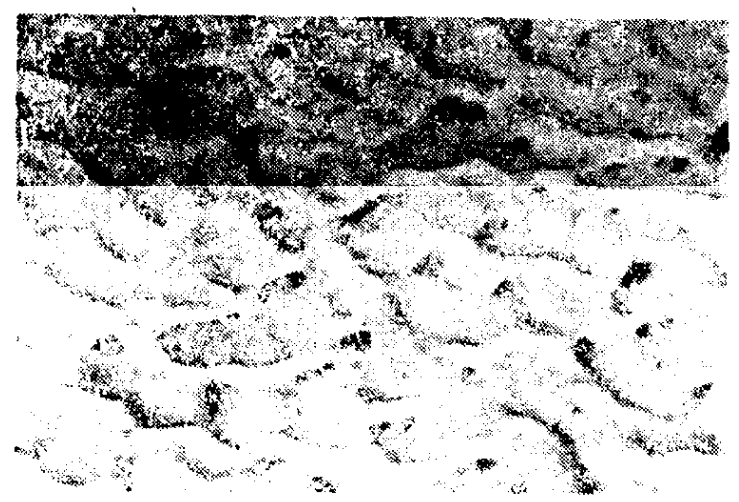

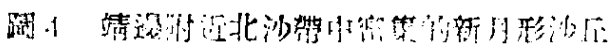

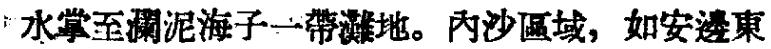
南孟海子沙、張家畔榆樹沙。清谷通風要道, 如 榆林七里沙中若干灌谷、波䧽西谷地、養石畔西 的沙地都可見到條形沙丘。

不論新月形沙丘或條形沙丘, 其形狀受風向 戀化而變形：（1）基幹沙塸及沙帶的新月形沙 丘, 迎風坡都面向西北, 即到夏季亦是如此。惟 經南風及東南風吹刮後, 每在新月形沙丘頂部座 生一小型沙丘, 高 1-3公尺, 迎風坡向南方或 東南方，興整個沙丘迎風坡向西北情形適屬相反， 而成複式沙丘。悠形沙丘高大者亦成複式沙丘, 但低矮條形沙丘受南風或東南風影響，可使迎風 坡全部逆轉面向東南或南方, 安透及張家唪一带 內沙虽常見到造種情形。(2)風越過迎風坡後, 在背風坡一面活動情形, 並不是單純呈旋渦狀。 在野外仔細親祭時，越過沙丘頂部的風，在丘頂 以下的空間確成旋渦狀逆指背風坡，而沙丘兩要 的風越過埡口後, 立即轉變算直於主風方向, 沿 背風坡面前進, 所謂頖崗風，遭從背風坡上風波 紋自上而下縱走情形亦可推知。因順崗風關係, 使沙丘兩覃的沙埂增大曲度, 如兩沙丘前後相距 不遠, 被沙埂連接起來, 可形成“鎝底沙”、“牛眼

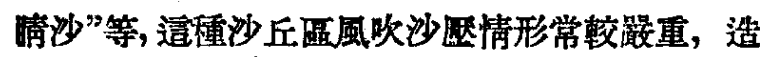

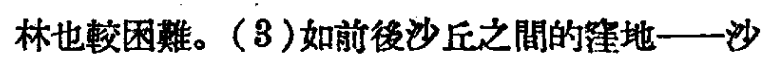

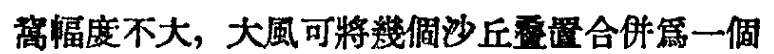
沙丘，背風坡一面坡度成階梯狀，表示受風吹刮 籍重。

丙. 高度

傸北沙丘高度裳較是正乾燥、低洼、多沙的 大沙漠區域的沙丘篇矮小（如塔里木盆地沙漠可 淒一百公尺左右)。在基幹沙帶和沙區中，一般沙 丘高度在 15-20 公尺，較高者亦只 30 公尺，只 有数地方，如海流鬼河以西有 2.5 公里寬的 地需・沙丘高達 40-60 公尺。基幹沙管和沙區中 部地等低涪的踓地或閉塞谷地，以及植物被覆較 很地方，普通沙丘高只 3-5 公尺，最高亦不過 7-8 公尺, 如榆林七里沙、辳家畔北沙的大海 子等地均是。

沙丘蒜和三邉內沙，或因面皘小、沙源少， 战因沙柆細、土基硬、風力相對地强鲃，丘 织，一般覅 3-4 公尺，較高者 8-10 公尺，低 者只 1-2 公尺。至於河岸沙一般高度僅 1-2 
公尺而已。

上面所說的是一般情形。望際上，在同一地

澓, 其高度興當地地勢、植被等情况有關。例如 在山坡或谷地背風一面, 坡地中腰沙丘高度最 大，自此向上或向下，高度都逐漸遞減，在魚河 堡北的山坡，墩兒渠一帶萑河西岸谷壁都可見到 逞種情形。至於植被的疏密，更深深影響沙丘高 度。如五十里沙兩端沙丘高達 40-60公尺, 而中 部固定沙地地面起伏少有超過 7-8 公尺的。張 家畔西馮家糿子沙 1950 年造林地已較未造 林 地 低 2-3 公尺。

丁. 移動方向和速度

沙粒在迎風坡上被刮向丘頂，又在丘頂後背 風坡落下，這樣便使沙丘從迎風坡一面逐潮向背 風坡一面移動。傸北沙丘一般自西北向東南移動。

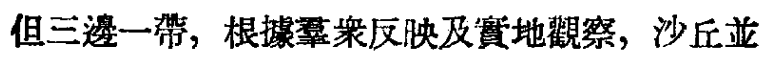
不是從西北向東南移㲜，而是自西向東，或甚至自 西南向東北移動，主其在靠近南山一帶更孚顯著。 造種現象可能由於地勢影響風向而引起: (1)西 北風變向。三邊的南山，北坡陡急，迫使西北風 轉變篇西風東吹。在張家畔榆樹沙，安邊孟海子 一带, 南山微作西南一東北走向，亦招致了西 北風轉變复西南風。主風風向既變，沙丘移動亦 酭之弦生變化。其他東西行梁地亦有濖種局部改 變風向的作用。（2）南風的作用。南山對於西北 風作用頗篇顯著，而對於夏季的南風北進却並不 影響。有些地方，如張家畔北沙四朴樹附近，沙 需有徽向北移現象。大坑眼附近，風玲空地已退

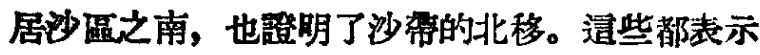
南風的作用澄超過了西北風自北向南的分力作 用。

至於移動速度，份待進一步詳細觀測。茲就 啁查時訪問所得和根據造林後沙斥厩樹情形作一 般的概批。

基幹沙帶和沙硈內，新月形沙丘交錯排列， 活度较大，沙粒又粗，所以沙丘移動速度較㯖， 中部高沙丘每年移動約 1-2 公尺, 沙帶沙區邊 移動校块，如大坑眼北沙帶南側，本均每年移 動 4 公尺。在基幹沙帶和沙區的经地和封閉谷地 中，条形少丘高度較低，阻風力量較小，移動速 度較快。㮬林西南天鵝海子、瓦渣梁每年移動 2 5 公尺。䅆林七里沙，樹木較稀處每年移動 3 -
4 公尺。

三這內沙和各地河岸少，沙展既薄，沙柆义

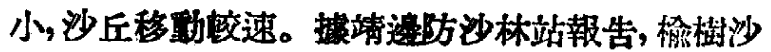
沙丘移動每年澾 7-15 公尺, 就地 1952 年春在

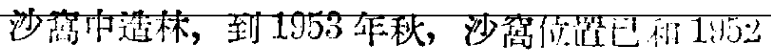

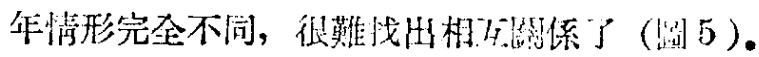

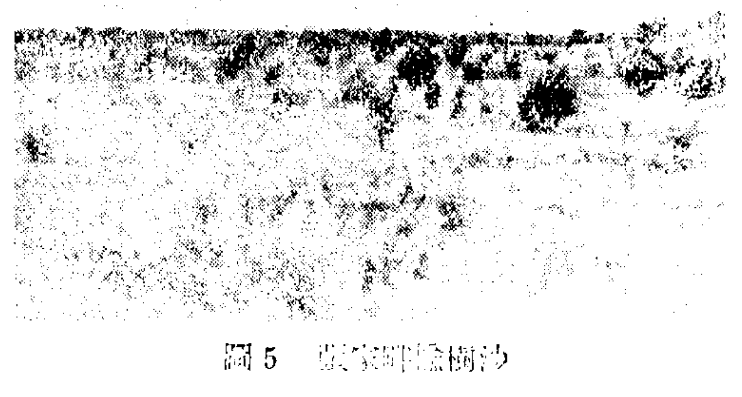

海改造前途

由於陝北沙丘的成因主要是人篇的，沙柆主 要是就地而起的, 我們不必躵心陮北將來會被伊 克昭盟沙粒㡠埋。自然植物如不受人畜破壤遭有 能力灇生起來。如果我們能充分了解沙丘的特性 及其發展規律，啨極加以改造，则不僅有信心可 以把沙區恢復編草原，而且遗可以進一步改造成 草原林地。茲提出幾调意見以供寒考:

1. 造林初期，因不明情况，曾在重踰地、乾 旱沙地、沙丘迎風坡高處造林，引起一些損失， 因此認識到硬幹是行不通的。在規劃方面也是㷟 樣，如果不進行切合實際的梁入的全面調查，在 地圖上繪出來來的林帶綫未必能如願造成。所以土 地利用的調查是十分必要的。

2. 陕北和伊克昭盟沙區，因各地地形、土㙲、

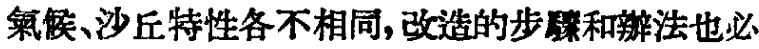
須因地制宜。(一)造林並不一定要载喬木林算 完成改造自然的任教。（二）下列各地方，必須梁 入研究, 總結經驗後, 再進行工作, 没有得出正 確結論時，不應大事造林：甲．粗沙、乾旱、盵 力美、“没底子”的沙區。乙．底基堅硬、沙展檑 薄、風力强勁的石泡泡地。丙．監蝓性極大地方。 丁. 光渠堅土、没有沙覆、地下水極梁地方。伐. 低矮條形沙丘、鍋底沙、牛眼睛沙等受風力吹刮 極强烈地方。

3. 就固沙效果來訊，草類不弱於稀疏杫林。 在榆林七里沙，樹堘巳有一定密度，而流沙刮強 仍極嚴重。至於各地單枝樹木，顯然會引起局部
11 月號
科學通 報
- $33 \bullet$ 
旋夙，根四周，被猢成凹地。这些都說明，在

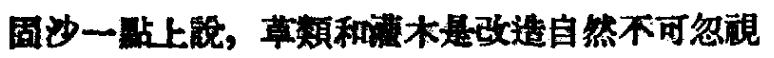

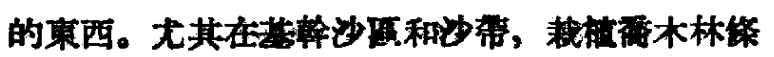

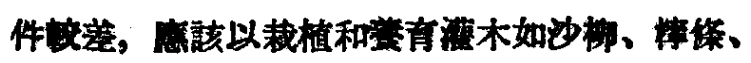

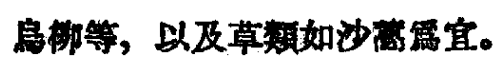

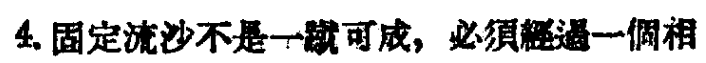

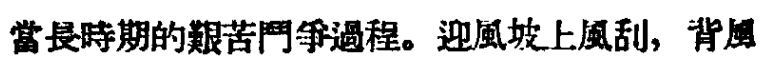

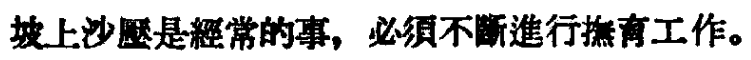

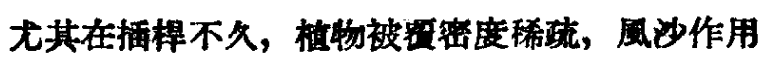

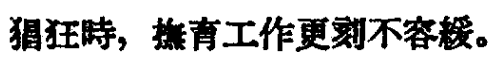

5. 就沙丘各部位既, 目下造林都在兩倜沙丘

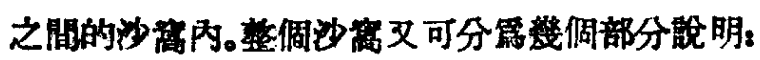

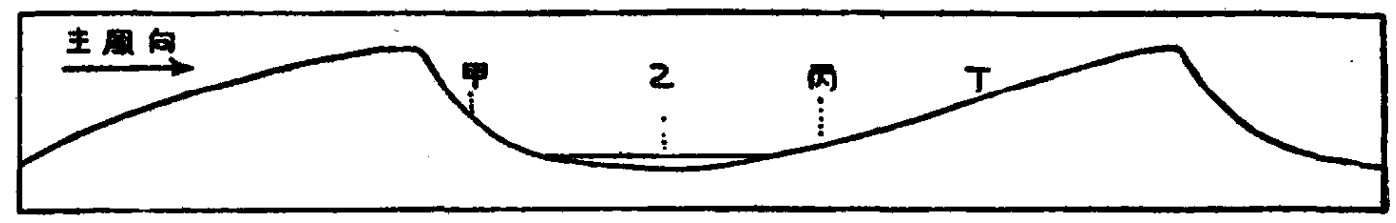

回6 甲.背風披 乙.海子丙.退沙畔 丁.迎蝈坡

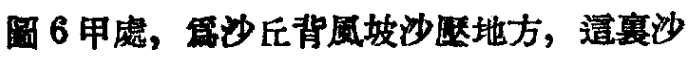

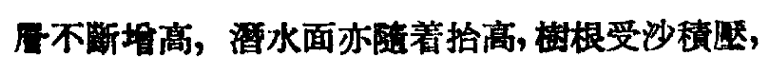
不會被風振撼，所以造熟造林成活率最高(圖7)。

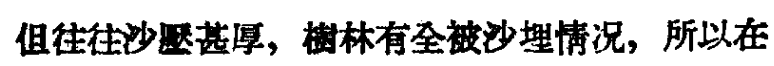
运喜，造林必須估計，樹木生長的速度要能和沙

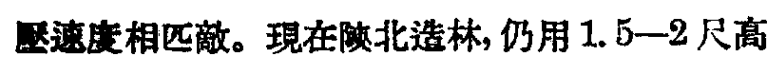

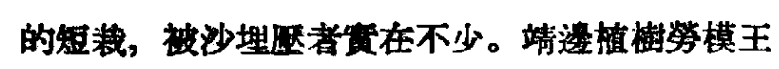

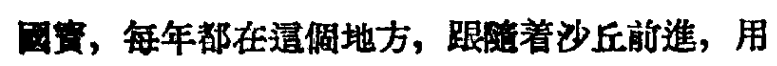

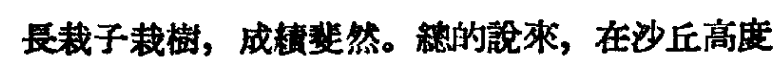

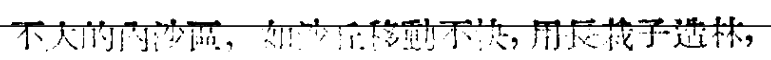

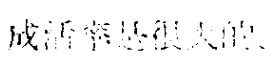

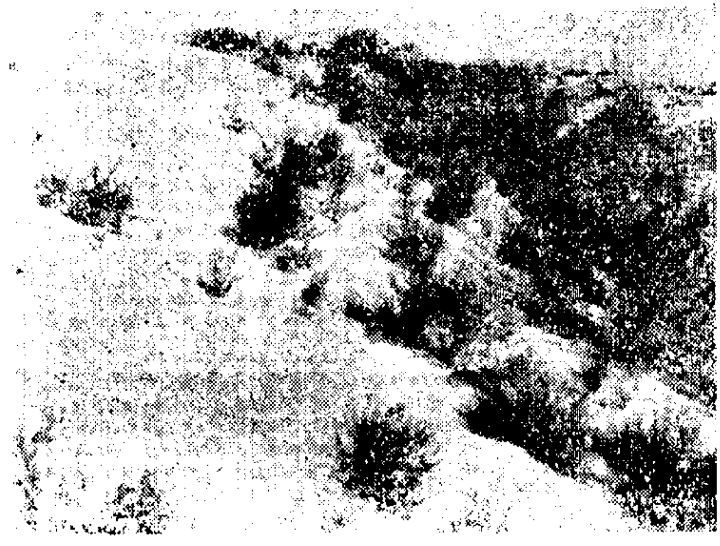

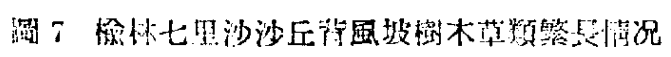

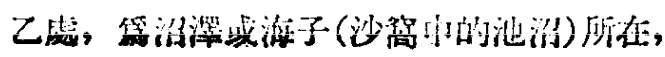

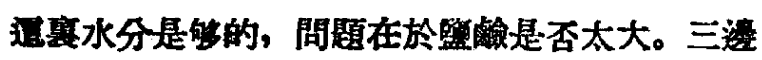

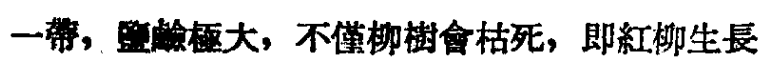
亦很不易。梌林一带, 鼠踰性較弱, 不僅沙柳能 在水中生長, 即柳樹也不枮萎。此外, 在沙简中

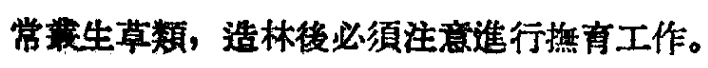

两處, 迎風坡低處約三分之一地位, 即所謂 退沙畔。远毫高度急低，沙刮程度急小，沙中含 水亦急多，樹木生長亦离好。忿向迎風坡而上， 困難亦等多。然而對沙丘進行鬥爭, 退沙畔雇該 是最主要地方, 否则, 栭沙攀力不能有效例弱。 退沙吽上造林應設置沙障, 最有效沙障是沿等高 綪用密桿或草類裁植成行, 行後再裁樹木。沙障

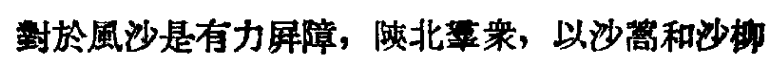
隔行相間裁植, 收到良好效果。

丁處，迎風坡高處三分之二地位。通赛風力 强大, 造林比較困難, 應以自然坊復第宜。

6. 榯種, 現傸北造林, 絕大部分孚旱柳, 其 次篇水桐。楖樹生長速度快, 生長條件不太渮, 樹幹可作建築材料和柴薪, 樹棐可飼牲音, 菜竞

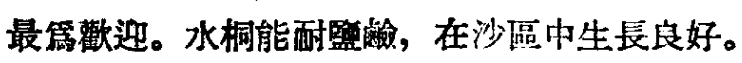
榆樹第優良樹種, 但必須選擇“有底子”沙地。青㛫 在趙石畔沙地中生長良好, 惟須帶根截植, 在大 量造林時受到限制, 是否可插桿栽植, 镸待㝬驗。 洋槐、臬栢能否立刻上沙, 也須進一步試驗和總 結。

灌木和草類方面。沙柳、烏柳、菻佟、紅楖， 均篇有用灌木。其中尤其沙柳最值得推廣, 在“沟 底子”沙丘區域亦可成活。䛪㷛在强石灰性地方可 以栽植。沙湾是多年生草本植物, 固沙效果是一 切植物中最大的, 在没有弡現其他有用而能適應 本地㻴境的草類前, 不僅應封沙讓它再生, 而且 遗可以人工载植。 